\title{
Baba Jukwa's Facebook page: A possible counter hegemonic space for political transformation in Zimbabwe
}

\author{
Stanley Mutetwa \\ University of the Western Cape
}

\section{INTRODUGTION AND BACKGROUND}

This study focuses on how the Baba Jukwa Facebook page has been appropriated as a potential counter hegemonic space for the circulation of public opinion during the run up till post 2013 harmonised elections in Zimbabwe. This current study wishes to explore the role played by social media in Zimbabwe in the run up to the 2013 election especially on Facebook through participation on the Baba Jukwa page. Focus will be on the nature of the discourses in the posts and how the participants on the page engaged in debates around these posts. I will also interrogate how the discourses in the posts on the Baba Jukwa Facebook page were taken up by the main stream media and how it also clashed with dominant political discourses as enshrined in government publications and web-sites. This will shed light on the impact of the page and how it enlarged the public sphere in the country as a counter hegemonic platform.

\subsection{Political and Legislative Framework of Zimbabwe}

Since the inception of independence in Zimbabwe in 1980, power has been in the hands of one political party and one president. In 1998, powerful opposition emerged in the form of the Zimbabwe Congress of Trade Unions (Z.C.T.U) under Secretary General Morgan Tsvangirai who later formed the leading political party Movement for Democratic Change (M.D.C), a development which changed the political landscape. This resulted in new draconian legislation being introduced to curtail freedom of expression and to silence all dissenting voices after the much disputed 2000 referendum and elections. The new legislations included the Access to Information and Protection of Privacy Act (AIPPA) of 2002 and the Public Order and Security Act (POSA) of 2002. These Acts were largely crafted to make sure that there was no direct access to state information and freedom of expression and assembly became a thing of the past as any gatherings of more than four people could lead to incarceration. 
Opposition parties expressed their disgruntlement over the introduction of the above acts which made it very difficult and dangerous to conduct rallies as all gatherings had to first be approved by the police, who have always been seen as aligned to the ruling party. The opposition parties also cried foul that they did not have access to both the print and broadcasting media which was also a state monopoly used to further the interests of the ruling party. The arrival of mobile phones and the Internet was therefore welcomed as creating new possibilities for citizens to produce more reliable information about the electoral process. To Castells et al (2007: 209) these new technologies provide 'many-to-many and one-to-one horizontal communication channels that bypass political or business control of communication'.

Since the 2000 elections, violence and vote rigging have become the norm in the Zimbabwean elections and allegations of vote rigging increased during the 2013 elections. Baba Jukwa, a self-styled 'ZANU PF insider' played a significant role in trying to unearth the rigging strategies and supposed attempts by 'his' party to silence dissenting voices from within and outside the party. It is against this background that this study will attempt to focus specifically on how people shared information in terms of discourses circulation against the background of repressive media regulation. The research is framed by theories of alternative media which argue that the emergence of mobile media and social network sites gave rise to new counter-hegemonic spaces and new forms of journalism that are neither institutionalized nor professional and whose extremism is reflected in both form and content (Moyo, 2008). The accessibility of GPRS enabled mobile phones with internet enhanced the people's ability to communicate, but even this was only to a limited extent because of access disparities as well as the fear of reprisal by the state if participants used their real identities.

\subsection{Baba Jukwa}

According to Moyo (2008) Zimbabweans started using mobile phones as tools for election monitoring during the 2008 presidential election. He highlights that for the first time the monitoring of the elections was taken from the observer teams to the citizens through their mobile phones.

Baba Jukwa is a faceless, nameless character with a disarming profile picture of a cartoon old man. He apparently is a whistleblower claiming to be a disgruntled ZANU- PF stalwart who is out to expose all machinations by what he calls, 'the evils of my party'. On numerous occasions he successfully predicted events that came to pass leading to his many followers building trust in him as an alternative source of reliable information. He exposed damaging details of high-level party meetings, allegations of voter fraud, and embarrassing gossip while issuing phone numbers for citizens to harass the officials in question (Regan-Sachs, 2013). He emerged on the Facebook social network site around March 2013 during the run up to the Zimbabwean presidential elections and instantly caused a sensation in the Zimbabwean social and political sphere. Baba Jukwa's online presence became an extension of public opinion - whether users agreed with him or not - his page was always flooded with commentary and opinions after each posting. These came not only from those in Zimbabwe but also from the diaspora who were eager for information 
on what was happening in their home country. Social media have been a vital link between Zimbabwean locals and the widely spread diaspora as they provided instant dissemination of opinions and information (Wo and Makokera, 2013). The other noteworthy aspect of social media, especially the Zimbabwean based Facebook pages, is the refreshing and flexible use of language which was heavily laden with undertones of satire, criticism, and caricature of the political elite. Notable among these was Baba Jukwa who used colloquial Zimbabwean English that reflected dynamic local, regional and global identities characteristic of the dispersed population. This project hopes to explore the links between these varieties and the identities they index.

\subsection{Significance of research project}

This research seeks to explore how the internet and social media can contribute to political change in authoritarian states. (Moyo, 2008; Castels et al. 2009). The gap this research will fill is showing how new technologies, especially mobile media were appropriated as tools for sharing news and public opinion formulation in the run up to the 2013 Zimbabwean elections. In the previous elections SMSs and blogs were used but the 2013 election was unique in that the social media through Facebook became a thorn in the flesh of the status quo as a whistle blower divulged damning inside information for the government while remaining anonymous. He rose greatly in popularity and managed to shape the agenda for the mainstream media. This study will thus attempt to explore whether citizen journalism has the potential to become a democratising force bridging the gap between the electorate and the elected as stipulated by the watchdog role of the media. This will be done through collaborating the debates on the page around topical current issues and coverage of the same events in the mainstream media. Attention will also be paid to how the discourse is shaped around common everyday language that the participants can identify with thus exploring the links between these varieties and the identities they index.

\subsection{Research problem}

This project focuses on the role played by the Baba Jukwa page in the 2013 elections in Zimbabwe which created a space for biting social media activism, so much so that some argue that one of the central political players in the elections was Baba Jukwa (Games, 2013) rather than the usual ZANU-PF and MDC-T political parties. Zimbabweans have been starved of independent reporting, with Reporters Without Borders (2013) ranking the country 133 rd of 170 nations in its World Press Freedom Index. This research thus seeks to show how the internet and social media have allowed people to contribute, share, hear and read information and different opinions about the state of their nation, which they did not readily have access to in previous elections.

\subsection{Research Questions}

The over-arching question is: How does the Baba Jukwa Facebook page create a new public sphere in which political debate can flourish? The project aims to explore how posts and comments on Baba Jukwa Facebook page reflect on national politics from a dissenting point of view and to ascertain how language is appropriated and used to construct Baba Jukwa and his followers as potential agents of change. 


\section{LITERATURE REVIEW}

\subsection{Social Media and Political Engagement}

Democracy entails participation by an active citizenry in shaping their destiny and it is in this light that classical theories of democracy place a 'high premium on self-rule by an engaged citizenry, dispersed power, and the common good pursued through collective deliberation' (White, 1997).

Citizens are susceptible to manipulation by those who would stir up their passions and prejudices or who would disburse substantial sums of money to manipulate public opinion to serve their own, narrow special interest (White, 1997). White further asserts that opinions and ideas must be advanced and defended in full light of public scrutiny. This is what he calls deliberation on current and national affairs and he reiterates that it should take place under technological anonymity. Sandel (1996) echoes this by asserting that a requirement for active citizenry is public spaces that gather citizens together, enable them to interpret their condition, and cultivate solidarity and civic engagement.

The most documented incidences of Internet utilisation for political mobilization in America are the 2004 campaign for Democratic Party presidential candidate and the 2003 MoveOn campaign against the Iraq war. Mobilising people in both cases was in many ways successful. However, in both cases, just like the Baba Jukwa Facebook revolution in Zimbabwe, the ultimately desired outcome was not successful as Howard Dean, the aspiring US candidate was edged out and the Iraq war proceeded unabated despite counter mobilisations in America.
The Egyptian revolution that led to the demise of Mubarak also saw the pivotal use of social media to topple him. Papachirissi and Oliveira (2012) propound that the Egyptian protests that led to the resignation of President Hosni Mubarak were 'organised through a network of heavy Twitter and Facebook use combined with other forms of interpersonal use'. Their study traces the news dissemination on twitter via the \#Egypt hashtag, exploring Twitter as a news reporting mechanism during the Egyptian uprising. The period 25 January to 25 February 2011 when this study was carried out saw access to mainstream media being blocked, foreign and native journalists being intimidated and access to the internet being controlled and ultimately shut down. As a result Twitter provided a continuous stream of events in real time throughout the crisis. Twitter is usually used to bring networked publics into being and into action during periods of political instability (Papachirissi and Oliveira, 2012). This is so as it generally calls for solidarity among publics, imagined or actual, that share a common set of goals. Hamdy (2010) reinforces this arguing that Twitter allows individuals to change the dynamics of conflict coverage and shape how events are covered, and possibly how history is written.

In Kenya, in the post-election crisis in 2008, Kuira and Makinen (2008) posit that the social media functioned as an 'alternative medium for citizen communication or participatory journalism'. This followed a ban on all broadcasting of election results after MwaiKibaki and RailaOdinga kept issuing conflicting results as each claimed victory to the media. During this ban only foreign media covered the election results as the local media was silent for fear of breaking the pronouncement. 
This consequently led to people soliciting alternative means of getting information and one method used was the Short Message Services (SMS) from mobile phones. As Ramsey (2008) cited in Kuira and Makinen (2008: 329) succinctly states: 'mobile phones were used to communicate and circumvent the media blackout' and SMS's were used to share news and feelings. In order to contain the effect of these messages the government disabled mass SMS since it was perceived to be 'provocative'. Coupled with the SMS was a rich package of social media that included wikis, weblogs, Facebook, Flickr, YouTube and Twitter that were also incorporated to organize and share information about the crisis and violence, as well as to raise funds. Kuira and Makinen's findings from interviews suggest that people felt more involved through the social media and 'dissatisfied with their limited possibilities as media consumers, many Kenyans chose to take active roles as 'citizen journalists,' reporting the ongoing situation and expressing their thoughts online' (2008: 329). Overall, they show that in Kenya during this crisis, social media allowed citizens an alternative public sphere and a richer platform to discuss their crisis. They also argue that the crisis proved the vitality of social media as a 'horizontal form' of news sharing. The major problems documented in this study are that despite opening a wider public sphere, social media and SMS were also hijacked to propagate ethnic prejudices and hate speech coupled with rumours as many bloggers took sides along ethnic lines.

Generally, the net reporting on elections in Zimbabwe has always been openly biased in favour of President Robert Mugabe's ruling ZANU PF party. According to Moyo (2008) this has resulted in a huge loss of credibility for both the electoral system and the state owned media. He then posits that the introduction of new technologies, including the internet and mobile phones, introduced new dynamics into political communication where citizens became pivotal in the campaign and the monitoring as well as observation of the election. These new forms of communication are fast eroding the monopoly of the former liberation movement governments, undercutting their liberation discourse that has had a stranglehold on election processes, and signalling the possibility of more open political spaces where divergent views can co-exist (Moyo, 2010).

To clearly analyse the underlying discourses in the Baba Jukwa posts and comments on Facebook, different theoretical frameworks will be employed. These will help in understanding the contexts that informed the political engagements on the page and the ideological underpinnings it entailed. Central to these theories will be Critical Discourse Analysis (CDA) and the sociolinguistic theories discussed below.

\section{THEORETICAL FRAMEWORK}

The theoretical framework for this study draws on a combination of Critical Discourse Analysis and sociolinguistic theories following the sociolinguistic approach to social media of Demeurt (2014), theories of performance and performativity (Coupland, 2007; Bell and Gibson, 2011; Pennycook, 2004; Butler, 1990), codeswitching and languaging (Ivkovic and Lotherington, 2009; Landry and Bourhis (1997) as well as theories of the alternative media (Atton, 1999) and the counter public sphere (Fraser, 1992, 1995). 
Using CDA I hope to explore the different ideologies and discourses that shapes the posts and comments in the Facebook data under analysis. I will examine the way in which Baba Jukwa positions himself discursively to appeal to his followers as well as to convincingly sell his counter ideology.

\subsection{Critical Discourse Analysis}

Critical Discourse Analysis has established itself as a field of crossdisciplinary teaching and research and has been widely drawn upon in the social sciences and the humanities. It has inspired critical language teaching at various levels and in various domains (Billig, 2003: 1). Chouliaraki and Fairclough (1999, in Billig 1999) concur that CDA provides for interdisciplinarity, for instance in this study where I will be using linguistic and social theories to analyse media texts.

\subsection{Sociolinguistic Theories}

The need to use sociolinguistic theories in this study emanates from the premise that digital communication raises important questions about language and social life. This includes questions about the nature of language and linguistic competence; about the roles of multimodality and intertextuality in creating meaning; about literacy and cognition, sociability and community, writing and aesthetics, as well as the realities and consequences of digital linguistic inequality (Demeurt, 2014). These sociolinguistic theories help to provide analytical lens at all three levels of Fairclough's framework. Key two key sociolinguistic concepts useful for my project will include the notions of performance and performativity (Chomsky, 1965; Hymes, 1974; Coupland, 2007; Pennycook,
2004 and Butler, 1990 a\&b) as well as codeswitching and languaging (Ivkovic and Lotherington, 2009; Landry and Bourhis, 1997). In light of the data under study a wide repertoire of Zimbabwe languages and varieties feature on the Baba Jukwa Facebook page and these perspectives will therefore shed light and a reflection on the dynamic local, regional and global identities indexed on the page.

\subsection{Methods}

Since this study is an analysis of interactions on Facebook as well as an analysis of media texts, a qualitative approach is best suited as this allows a researcher to access the rich complexity of the phenomenon under study (Trochim, 2005). A sample of about 300 posts from the Baba Jukwa Facebook page during the run up to the 2013 harmonised elections in Zimbabwe (between May and August 2013) will be used. The posts will be copied into a word document. A content and discourse analysis of the issues addressed in these posts will then follow and much attention will be put on analyzing underlying discourses influencing the nature of the posts as well as the comments on the page. Also integral in unearthing the counter-discourses is the need to know the official state discourses thus data will also be gathered from mainstream media editorials and government websites as well as relevant literature that captures the dominant discourses. As part of the data the researcher will also critically analyse Baba Jukwa's contributions to the mainstream media especially instances where he influenced the agenda for the main media houses and also his contributions on media houses where he was made a columnist. These include The Zimbabwean newspaper and 
two online news websites namely ZimEye and NewZimbabwe.Com where he was a contributor as well as the Daily news that extensively covered on the page during the same period.

\subsection{Data Analysis}

This study will largely employ content and discourse analytic methods for analysis of data. Content analysis is defined as any technique for making inferences by systematically and objectively identifying special characteristics of messages (Hosti, 1998 in Berg, 2001: 240). Content analysis can be subdivided into manifest and latent content analysis. In manifest content analysis the elements of the data for analysis are physically present or obvious while in latent content analysis the meanings are underlying and need to be inferred and supported by evidence.

To show how political discourses are constructed in the texts I shall critically scrutinize the broader context of the posts and the comments from Baba Jukwa and his followers. Much focus will be put on the type of thematic (or content) concerns raised and how they are linguistically discussed by paying attention to choices of linguistic variety and register. This will help to uncover the ideological underpinnings in the political debates on the Facebook page as language is always a carrier of ideologies.

\section{BIBLIOGRAPHY}

Atton, Chris. 1999. 'A Reassessment of the Alternative Press', Media, Culture E Society 21: 51-76.

Bell, Allan, and Andy, Gibson. 2011. Staging Language: An Introduction to the Sociolinguistics of Performance. Journal of Sociolinguistics 15(5).555-572.

Billig, Michael. 2003. 'Critical Discourse Analysis and the Rhetoric of Critique', in G, Weiss, and Ruth, Wodak. (eds) Critical Discourse Analysis: Theory and Interdisciplinarity. New York: Palgrave MacMillan.

Bruns, Axel. 2011. Towards distributed citizen participation: lessons from WikiLeaks and the Queensland Floods. In Parycek, Peter, Kripp, Manuel J, and Noella, Edelmann (Eds.) CeDEM11: Proceedings of the International Conference for E-Democracy and Open Government, Edition Donau-UniversitätKrems, Danube-University Krems, Austria, 35-52.

Boucher, Geoff. 2006. The Politics of Performativity. A Critique of Judith Butler. Parrhesia 1 112-141.

Bugalo, Bridgette. 2013. Citizen Journalism, a fifth estate, thrived during Zimbabwe's Elections. The Media Observatory. Wits Journalism (Research, Analysis and Commentary) http://www.journalism. co.za/index.php/research-papers/5474citizen-journalism-a-fifth-estate-thrivedduring-zimbabwe-s-elections.html Accessed 05/09/2013

Butler, Judith. 1999 [1990].Gender Trouble: Feminism and the Subversion of Identity (Subversive bodily acts, IV Bodily Inscriptions, Performative Subversions). New York: Routledge.

Castells, Manuel., Mireia, Fernandez-Adevol, and Jack Linchuan, Qiu. 2007. Mobile Communication and Society: A Global Perspective. Cambridge, Massachusetts \& London, UK: The MIT Press

Chouliaraki, Lilie, and Norman, Fairclough. 1999. Discourse in late Modernity. Edinburgh: Edinburgh University Press.

Christians, Clifford, G, Theodore, L, Glasser, Denis, McQuail, Kaarle, Nordenstreng, and Robert, A, White. 2009. Normative Theories of the Media: Journalism in Democratic Societies. Illinois: University Of Illinois.

Deumert, Ana. 2014. Sociolinguistics and Mobile Communication. Edinburgh: EUP

Downing, D.H. John. 2001 .Radical Media: Rebellious Communication and Social Movements. Thousand Oaks, CA: Sage. 
Dvorak, C. John. 2006. The Folly of

Citizen Journalism.www. pcmag/ article2/0,2817,2018636,00.asp accessed $27 / 07 / 2014$

Elspeth, Tilley, and John, Cokley. 2008.

Deconstructing the discourse of citizen Journalism: Who says what and why it matters.Pacific Journalism Review 14 (1) 94-114

Fairclough, Norman. 1992. Discourse and Social Change. Cambridge: Polity.

Fairclough, Norman. 1995. Media Discourse. London: Arnold Publishers.

Fraser, Nancy. 1992. 'Rethinking the Public Sphere: A Contribution to the Critique of Actually Existing Democracy', pp. 109-42 in C. Calhoun (ed.) Habermas and the Public Sphere. Cambridge, MA: MIT Press.

Fraser, Nancy. 1995. Politics, culture, and the public sphere: Toward a postmodern conception. Social postmodernism: Beyond identity politics, 287-312.

Fuchs, Christain. 2010. Alternative Media as Critical Media. European Journal of Social Theory. 13(2) 173-192

Gillmor, Dan. 2006. We the Media: Grassroots Journalism by the People, for the People. Sebastopol: O'Reilly Media.

Goode, Luke. 2010. Social News, citizen Journalism and democracy. New Media Society 11 (8): 1287-1305

Haas, Tanni. 2004. 'Alternative Media, Public Journalism and the Pursuit of Democratization', Journalism Studies 5: 115-21.

Habermas, Jurgen. 1992. 'Further Reflections on the Public Sphere', pp. 421-61 in C. Calhoun (ed.) Habermas and the Public Sphere. Cambridge, MA: MIT Press.

Hamdy, Naila. 2010. Arab Media adopt citizen journalism to change the dynamics of conflict coverage. Global Media Journal: Arab Edition 1 (1) 3-15.

Hamilton, J.A. 2000. 'Alternative Media: Conceptual Difficulties, Critical Possibilities', Journal of Communication Inquiry 24: 357-78.

Hertog, K, James, and McLeod, M. Douglas. 1995. 'Anarchists Wreak
Havoc in Downtown Minneapolis: A Multi-Level Study of Media Coverage of Radical Protest', Journalism and Mass Communication Monographs 151. Columbia, SC: Association for Education in Journalism and Mass Communication.

Ivkovic, Dejan, and Heather, Lotherington. 2009. Multilingualism in Cyberspace: Conceptualising the Virtual.

Koopmans, Ruud. 2004. Protest in time and space: The evolution of waves of contention. In D. Snow, S. A. Soule, and H. Kriesi (Eds.), The Blackwell companion to social movements 19-46. Malden, MA: Blackwell Publishing.

Lasica, D. Joseph. 2003. 'What is Participatory Journalism?' Online Journalism Review, URL (consulted September 2008): http://www.ojr.org/ojr/ workplace/1060217106.php

Landry, Rodrigue, and Richard,Y, Bourhis. 1997. Linguistic landscape and ethnolinguistic vitality: An empirical study. Journal of Language and Social Psychology 16 (1) 23-49

Maarit, Makinen, and Mary, Kuira. 2008. Social Media and Post-election crisis in Kenya. The International Journal of Politics/ Press 13(3) 328-335.

McLeod, M. Douglas, and James, K, Hertog. 1999. 'Social Control, Social Change and the Mass Media's Role in the Regulation of Protest Groups', pp. 305-32 in D. Demers and K. Viswanath (eds) Mass Media, Social Control and Social Change: A Macro- Social Perspective. Ames: Iowa State University Press.

Moyo, Dumisani. 2006. The New Media as Monitors of Democracy: Mobile Phones and Zimbabwe's 2008 Election. Paper presented at the Conference on Election Processes, Liberation Movements and Democratic Change in Africa; 8-11 April 2010; Maputo

Papaccharissi, Zizi, and Maria de Fatima Oliveira. 2012. Affective News and Networked Publics: The Rhythms of News Storytelling on \#Egypt. Journal of Communication 62: 266-282.

Pennycook, Alastair. 2004. Critical moments in a TESOL praxicum. In B. Norton 
and K. Toohey (eds). Critical Pedagogies and Language Learning 327-345.

Cambridge: Cambridge University Press.

Postal \& Telecommunications Regulatory

Authority of Zimbabwe (POTRAZ)

Quarterly Sector Statistics Report - 2nd

Quarter Of 2012 http://www.potraz.gov.

zw/index.php/publications-and-statistics/

statistics/network-capacities.html

accessed 05/09/2013.

Rauch, Jennifer. 2007. Activists as

Interpretive Communities: Rituals of

Consumption and Interaction in an

Alternative Media Audience. Media,

Culture Eo Society 29(6): 994-1013.

Reporters without borders. 2013. World Press

Freedom Index. http://en.rsf.org/press-

freedom-index-2013,1054.html Accessed 06 August 2014

Sachs, Rebecca. 2013. Zimbabwe: Baba Jukwa vs. Mugabe - the Man on Facebook Standing Up to Zimbabwe's President http://allafrica. com/stories/201308011328.html.

Sandel, Michael. 1996. Democracy's Discontent. Harvard University Press

Seargeant, Philip, and Caroline, Tagg. 2011. English on the Internet and a 'PostVarieties' Approach to Language. World Englishes 30: 496-514.

Shankar, Shalini, and Jillian, R, Cavanaugh. 2012. Language and Materiality in Global Capitalism. Annual Review of Anthropology 41: 355-369.

Staff Reporter. 2013. Chindorichininga dies. http//:www. newsday.co.zw/2013/06/20/ chindori-chininga-dies/ Accessed

05/09/2013.

Staff writer. 2013. Zimbabwe's Internet

Subscribers Double http://www.

theindependent.co.zw/2013/02/22/

zimbabwes-internet-subscribers-double/

Accessed 05/09/2013

Traber, Michael. 1985. Alternative

Journalism, Alternative Media.

Communication Resources, No. 7.

London: World Association for Christian

Communication.

The Zimbabwe Mail, March 14, 2012,

"Zimbabweans look to the Internet

for truth and freedom," http://www.

thezimbabwemail.com/zimbabwe/7436.

html. Accessed 05/09/2013

Van Dijk, Teun, A. 2001. 'Critical Discourse Analysis' in Deborah, Schiffrin, Deborah, Tannen, and Heidi, E, Hamilton. (eds)

The Handbook of Discourse Analysis.

Oxford: Blackwell Publishers.

Van Dijk, Teun, A. 2003. Discourse and

Manipulation. Discourse Society. 17 (2)

359-383

White, S. Charles. 1997. Citizen

Participation and the Internet: Prospects for Civic Deliberation in the Information Age. The Social Studies 88(1)

Wu, Yu-Shan, and Catherine, G, Makorera. 2013. Zimbabwe: Baba Jukwa, Social Media and Zimbabwe's Future http://allafrica.com/ stories/201308011328.html Accessed 05/09/2013 www.itu.int/ent/ITU-D/

Statistics/Pages/stat/default.aspx accessed 20 July 2015. 